\title{
Author Correction: Glacigenic sedimentation pulses triggered post-glacial gas hydrate dissociation
}

\author{
Jens Karstens 1,2, Haflidi Haflidason1, Lukas W.M. Becker ${ }^{1}$, Christian Berndt (i) 2, Lars Rüpke², Sverre Planke ${ }^{3,4}$,
} Volker Liebetrau ${ }^{2}$, Mark Schmidt ${ }^{2} \&$ Jürgen Mienert ${ }^{5}$

Correction to: Nature Communications https://doi.org/10.1038/s41467-018-03043-z, published online 12 February 2018

The original version of this Article contained an error in the second sentence of the Abstract, which incorrectly read 'They are stable under high pressure and low, but react sensitively to environmental changes.' The correct version adds 'temperature' after 'low'. This has been corrected in both the PDF and HTML versions of the Article.

Published online: 07 March 2018

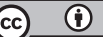

Open Access This article is licensed under a Creative Commons Attribution 4.0 International License, which permits use, sharing, adaptation, distribution and reproduction in any medium or format, as long as you give appropriate credit to the original author(s) and the source, provide a link to the Creative Commons license, and indicate if changes were made. The images or other third party material in this article are included in the article's Creative Commons license, unless indicated otherwise in a credit line to the material. If material is not included in the article's Creative Commons license and your intended use is not permitted by statutory regulation or exceeds the permitted use, you will need to obtain permission directly from the copyright holder. To view a copy of this license, visit http://creativecommons.org/licenses/by/4.0/.

(c) The Author(s) 2018

\footnotetext{
${ }^{1}$ Department of Earth Science, University of Bergen, Bergen, Norway. ${ }^{2}$ GEOMAR Helmholtz Centre for Ocean Research Kiel, Kiel, Germany. ${ }^{3}$ Volcanic Basin Petroleum Research (VBPR), Oslo, Norway. ${ }^{4}$ The Centre for Earth Evolution and Dynamics (CEED), University of Oslo, Oslo, Norway. ${ }^{5}$ CAGE-Centre for Arctic Gas Hydrate, Environment and Climate, UiT-The Arctic University of Norway, Tromsø, Norway. Correspondence and requests for materials should be addressed to J.K. (email: jkarstens@geomar.de)
} 